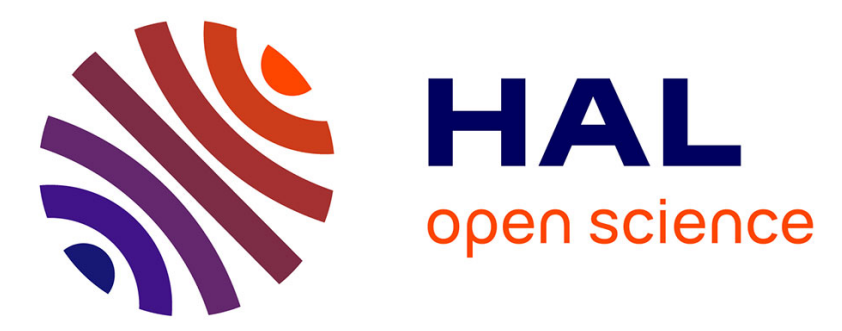

\title{
Presence of specific growth hormone binding sites in rainbow trout (Oncorhynchus mykiss) tissues: characterization of the hepatic receptor
}

\author{
K. Yao, Ping-De Niu, Florence Le Gac, Pierre-Yves Le Bail
}

\section{To cite this version:}

K. Yao, Ping-De Niu, Florence Le Gac, Pierre-Yves Le Bail. Presence of specific growth hormone binding sites in rainbow trout (Oncorhynchus mykiss) tissues : characterization of the hepatic receptor. General and Comparative Endocrinology, 1991, 81, pp.72-82. 10.1016/0016-6480(91)90126-Q . hal02716125

\author{
HAL Id: hal-02716125 \\ https://hal.inrae.fr/hal-02716125
}

Submitted on 1 Jun 2020

HAL is a multi-disciplinary open access archive for the deposit and dissemination of scientific research documents, whether they are published or not. The documents may come from teaching and research institutions in France or abroad, or from public or private research centers.
L'archive ouverte pluridisciplinaire HAL, est destinée au dépôt et à la diffusion de documents scientifiques de niveau recherche, publiés ou non, émanant des établissements d'enseignement et de recherche français ou étrangers, des laboratoires publics ou privés. 


\title{
Presence of Specific Growth Hormone Binding Sites in Rainbow Trout (Oncorhynchus mykiss) Tissues: Characterization of the Hepatic Receptor ${ }^{1}$
}

\author{
Kouakou Yao, Ping-De Niu, Florence Le Gac, and Pierre-Yves Le Bail ${ }^{2}$ \\ Laboratoire de Physiologie des Poissons, INRA. Campus de Beaulieu, 35042 Rennes Cedex. France
}

Accepted January 19, 1990

\begin{abstract}
The present work outlines the presence of specific binding for chinook salmon growth hormone (sGH) in different tissue preparations of rainbow trout. Optimal incubation conditions $\left(\mathrm{pH}\right.$, Tris, $\mathrm{MgCl}_{2}$ ) were determined. Specific binding was very sensitive to salt concentration during incubation. The specific binding reached a plateau after 15 and $25 \mathrm{hr}$ of incubation at 12 and $4^{\circ}$. At $20^{\circ}$, specific and nonspecific binding were not stable. Specific binding dissociation was slower than association and was only partial. The binding was saturable $\left(B_{\max }=187 \pm 167 \mathrm{pmol}\right)$, of high affinity $\left(K_{a}=2.4 \pm 0.810^{9} \mathrm{M}^{-1}\right)$, and very specific for $\mathrm{GH}$, properties which are in agreement with the characteristics of hormonal receptors. Sea bream and mammalian GH appeared 2- and 30-fold, respectively, less potent than cold $\mathrm{sGH}_{2}$ for displacing ${ }^{125} \mathrm{I}-\mathrm{sGH}_{2}$. Tissue preparations from ovary, testis, fat, skin, cartilage, gill, blood pellet, brain, spleen, kidney, and muscle showed significant saturable binding. 1991 Academic Press, Inc.
\end{abstract}

In fish, interest in pituitary hormone receptors is increasing. In salmonids, using a homologous system, GtH receptors have been characterized in ovary (Salmon et al., 1984; Breton et al., 1986; Kanamori et al., 1987; Kanamori and Nagahama, 1988; Breton and Sambroni, 1989) and in testis (Le Gac et al., 1988). Only one study on prolactin (PRL) receptors was done with homologous hormone in tilapia kidney (Fryer, 1979a). Its presence in testis, ovary, intestine, gills, liver, and kidney was detected using ovine PRL (Edery et al., 1984; Dauder et al., 1990a,b).

Using bovine growth hormone (bGH), Tarpey and Nicoll (1985) demonstrated the presence of a specific receptor in the liver of mudsucker (Gillichthys mirabilis) and sturgeon (Acipenser transmontanus). Char-

${ }^{1}$ This work was presented in part at the XIth International Symposium On Comparative Endocrinology, Malaga, Spain, May 14-20, 1989.

${ }^{2}$ To whom requests for reprints should be directed. acterization of tilapia (Sarotherodon mossambicus) liver $\mathrm{GH}$ receptor was done by Fryer (1979b) using homologous hormone and specific binding was noted in gill and kidney microsomal membrane fraction. Using this last hormone, specific binding was also found in the liver of mudsucker, rainbow trout (Oncorhynchus mykiss), and chinook salmon (O. tshawytscha) (Fryer, 1979b), and one study indicated that stunted coho salmon $(O$. kisutch) have a decreased ability to bind GH by liver (Fryer and Bern, 1979). More recently, using chinook salmon GH, we demonstrated the presence of saturable binding in rainbow trout liver (Le Bail et al., 1989; Niu et al., submitted for publication).

The aim of this study was to characterize, in vitro, the specific binding of salmonid growth hormone ( $\mathrm{sGH}$ ) to rainbow trout liver. This paper reports on the incubation conditions, association and dissociation kinetics, hormonal specificity, determination of affinity constant and number of liver 
binding sites, and the presence of saturable binding in putative target tissues.

\section{MATERIALS AND METHODS}

\section{Experimental Animals}

One-year-old rainbow trout $(O$. mykiss) reared at Cornec (Finistère) fish farm were used. They were acclimated for more than 2 weeks in a recycling water unit, at $15^{\circ}$, under a natural photoperiod and were fed ad libitum.

\section{Hormones}

The purification of chinook salmon (O. tshawyscha) $\mathrm{GH}\left(\mathrm{sGH}_{1}\right.$ and $\mathrm{sGH}_{2}$ ) has been described previously (Le Bail et al., 1989). Sea bream (Sparus aurata) GH (dGH) (Pagelson, Zohar, and Le Bail, unpublished data) and chinook GtH (sGtH) (Breton et al., 1978), and PRL (sPRL) (Prunet and Houdebine, 1984) were purified in our laboratory. Ovine $\mathrm{GH}(\mathrm{oGH})$ and $\mathrm{FSH}$ (oFSH) and bovine GH (bGH) and TSH (bTSH) were obtained from the National Institute of Arthritis and Metabolic Diseases, National Institute of Health (Bethesda, MD). Recombinant human ( $\mathrm{rGGH}$ ) and bovine (rbGH) GH were a gift from Sanofi and Monsanto, respectively.

\section{Preparation of ${ }^{125} \mathrm{I-s} \mathrm{SH}_{2}$}

Five micrograms of chinook salmon $\mathrm{GH}_{2}$ was iodinated by the chloramine-T method (Greenwood et al., 1963) with the modification introduced by Martal (1972). Separation of radiolabeled $\mathrm{sGH}_{2}$ from free ${ }^{125} \mathrm{I}$ was carried out by chromatography on a PD10 column (Pharmacia). The specific radioactivity ( $\mathrm{SA}=$ radioactivity content/protein content) varied between 60 and $90 \mu \mathrm{Ci} / \mu \mathrm{g}$. The specific radioactivity was corrected with time, taking into account deiodination of the hormone and decrease of iodine radioactivity.

\section{Preparation of Receptor Material}

The entire procedure was carried out at $4^{\circ}$ using chilled buffers. Tissues were minced and then homogenized in $20 \mathrm{~m} M$ Tris, $5 \mathrm{mM} \mathrm{MgCl}_{2}$ (pH 7.5) containing $1 \mathrm{mM}$ PMSF (5 ml/g initial tissue weight). A Polytron tissue grinder, with two successive 15 -sec bursts at high speed, was used. The homogenate was passed through cheesecloth and centrifuged $(3000 \mathrm{~g} \times 30 \mathrm{~min})$. The pellet was resuspended in the same buffer and centrifuged again. The resulting pellet was resuspended in the assay buffer ( $20 \mathrm{mM}$ Tris, $5 \mathrm{mM} \mathrm{MgCl}_{2}$, $0.25 \mathrm{mg} / \mathrm{ml}$ soya bean trypsin inhibitor, $0.5 \mathrm{mM}$ ascorbic acid, $1 \% \mathrm{BSA}, 0.1 \%$ sodium azide, $\mathrm{pH} 7.5$ ) generally at $2 \mathrm{~g}$ wet initial tissue weight $/ \mathrm{ml}(\times 2)$. This suspension was used directly in the binding assay.

Nose cartilage was powdered in liquid nitrogen us- ing a mortar, and then incubation was done as described above.

\section{Binding Assay Procedure}

Assays were performed in 5-ml polystyrene tubes (LES C ${ }^{\text {ic }}$ ) containing $100 \mu \mathrm{l}$ of ${ }^{125} \mathrm{I}_{-} \mathrm{sGH}_{2}$ (generally $10,000 \mathrm{cpm}$ ), $100 \mu \mathrm{l}$ of assay buffer containing, if required, unlabeled hormone as described under Results. After vortexing, the tubes were incubated (generally at $12^{\circ}$ for $20 \mathrm{hr}$ ). At the end of incubation, $3 \mathrm{ml}$ of chilled assay buffer was added and the tubes were centrifuged at $3000 \mathrm{~g}$ for $10 \mathrm{~min}$. The supernatant was discarded and the pellet-associated radioactivity was counted in a Packard (Multi-Prias 2) gamma counter (75\% efficiency).

The nonspecific binding (NSB) was determined in the presence of an excess of unlabeled sGH $(1000 \mathrm{ng} /$ tube). The specifically bound (SB) radioactivity was calculated by subtracting the nonspecifically bound (mean of duplicate determination) from the total bound (TB) radioactivity (mean of duplicate determination).

\section{Calculation}

Affinity constants $\left(K_{a}\right)$ and binding capacities $\left(B_{\max }\right)$ were estimated from the Scatchard (1949) transformation of saturation curves for specific binding of ${ }^{125}$ I$\mathrm{SGH}_{2}$ to trout liver preparation. The maximum binding experiment showed that only a fraction of the hormone had the capacity to bind to the receptor which varied from 30 to $50 \%$, according to the labeling and the age of the iodinated hormone. Therefore, the amount of hormone added to each tube was corrected by this factor before doing the Scatchard transformation.

\section{RESULTS}

${ }^{125} \mathrm{I}_{-\mathrm{s}} \mathrm{GH}_{2}$ Quality

When the labeling reaction medium was chromatographed in an ACA 54 (IBF) column, ${ }^{125} \mathrm{I}_{-} \mathrm{SGH}_{2}$ binding activity was mainly observed in the first peak, in which the $B / T$ ratio measured appeared relatively constant (Fig. 1). Therefore, the following separation of ${ }^{125} \mathrm{I}-\mathrm{sGH}$ from free ${ }^{125} \mathrm{I}$ was performed in a column of lesser resolution but of more convenience (PD10).

\section{Incubation Conditions}

Figure 2 shows the effect of incubation buffer $\mathrm{pH}$ on binding of labeled $\mathrm{sGH}$ to 


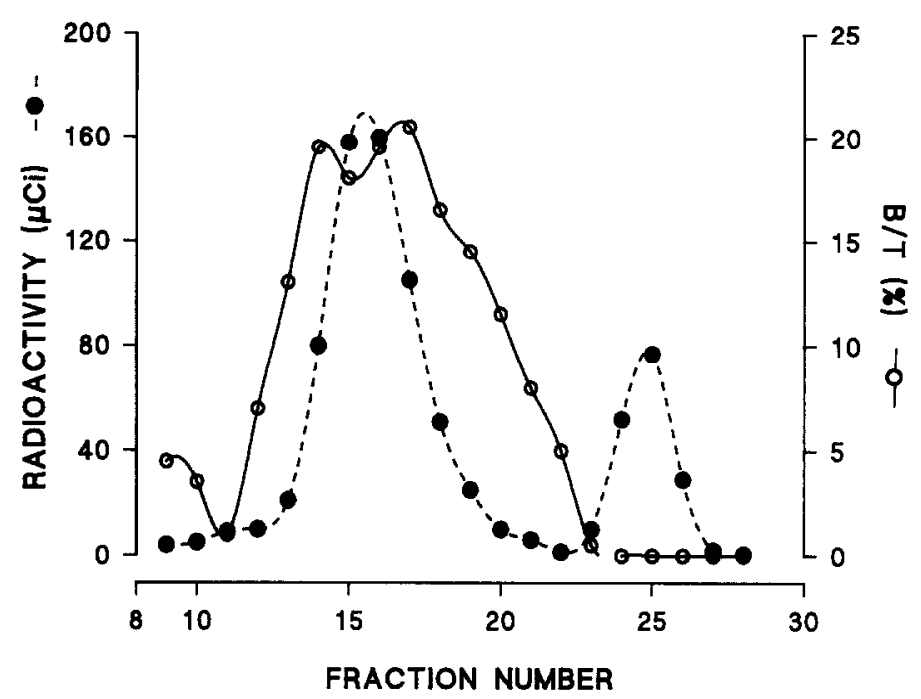

FIG. 1. Specific binding activity of ${ }^{125} \mathrm{I}_{-} \mathrm{sGH}_{2}$ to liver preparation. After iodination, labeled $\mathrm{sGH}_{2}$ was chromatographed on an ACA $54(22 \times 0.6 \mathrm{~cm})$ column, and $20,000 \mathrm{cpm} / 100 \mu \mathrm{l}$ was incubated $(20$ $\left.\mathrm{hr}, 4^{\circ}\right)$ with $100 \mu \mathrm{l}$ of liver preparation $(0.5 \mathrm{~g} / \mathrm{ml}$ wet lissue) and $100 \mu \mathrm{l}$ of buffer, with cold sGH $(1 \mu \mathrm{g})$ added or omitted. Specific binding was expressed as a percentage of total radioactivity added $(B / T)$.

trout liver preparations. Maximum specific binding occurred between $\mathrm{pH} 6.5$ and $\mathrm{pH} 8$. The nonspecific binding plot started at high values at low $\mathrm{pH}$ and then decreased dramatically up until $\mathrm{pH} 7$ and more slowly thereafter. The best ratio between specific and nonspecific binding was obtained at pH 7.5.

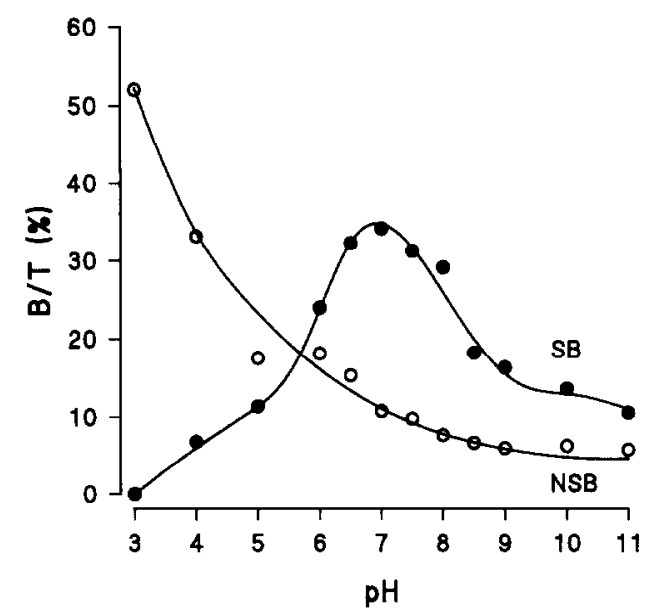

Fig. 2. Effect of $\mathrm{pH}$ on the specific (SB) and nonspecific (NSB) binding of ${ }^{125} \mathrm{I}-\mathrm{sGH}$ to liver preparation ( $100 \mu \mathrm{l} \mathrm{of} 1 \mathrm{~g} / \mathrm{ml}$ wet tissue). The incubation conditions are described under Materials and Methods.
During incubation $\mathrm{MgCl}_{2}$ concentrations greater than $10 \mathrm{~m} M$ decreased the specific binding (Fig. 3). A similar effect was obtained with Tris concentrations greater than $20 \mathrm{mM}$. Nonspecific binding was not sensitive to salt concentration at $\mathrm{pH} 7.5$. The most favorable conditions appeared to be $20 \mathrm{~m} M$ Tris (for a high buffering capacity) and $5 \mathrm{mM} \mathrm{MgCl}$ and thus were used for the following studies.

\section{Association and Dissociation Studies}

The effect of incubation duration on the receptor hormone complex formation was studied at $20^{\circ}, 12^{\circ}$, and $4^{\circ}$. Under these conditions, apparent equilibrium of the specific binding was reached after 5,15 , and $25 \mathrm{hr}$ of incubation, respectively (Fig. 4), after which specific binding was stable up until $60 \mathrm{hr}$ of incubation at 12 and $4^{\circ}$. At $20^{\circ}$, specific binding decreased after $20 \mathrm{hr}$. Nonspecific binding increased quickly during the first $5 \mathrm{hr}$ of incubation, then appeared relatively stable at $4^{\circ}$, increased slowly at $12^{\circ}$, and increased dramatically at $20^{\circ}$.

Dissociation of $\mathrm{sGH}$ from its binding 


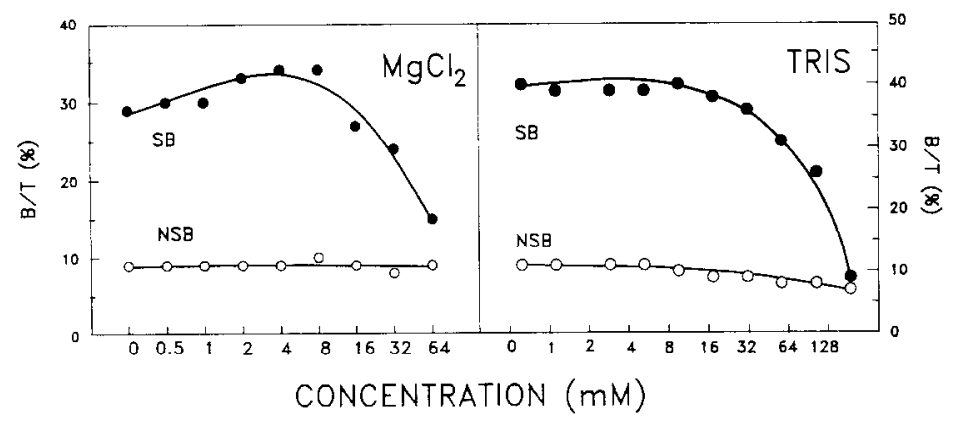

FIG. 3. Effect of $\mathrm{MgCl}_{2}$ and Tris concentration on the specific (SB) and nonspecific (NSB) binding of ${ }^{125} \mathrm{I}-\mathrm{sGH}_{2}$ to liver preparation $\left(100 \mu \mathrm{l}\right.$ of $1 \mathrm{~g} / \mathrm{ml}$ wet tissue). $\mathrm{MgCl}_{2}$ and Tris concentrations were expressed as final concentrations in millimoles.

sites was investigated after preincubation $\left(12^{\circ}, 20 \mathrm{hr}\right)$ of the tissue preparation with labeled sGH. Because control specific binding showed some minor variation during this long incubation period (Fig. 5A), results from the dissociation kinetics were expressed as percentages of the control values for each point of the study (Fig. 5B). Under these conditions, dissociation appeared relatively rapid during the first $48 \mathrm{hr}$ (about $45 \%$ ), after which specific binding was nearly stable for at least 13 days of incubation.

\section{Saturation and Competition Experiments}

Figure 6 shows the percentage of labeled sGH binding to increasing amounts of liver preparation. Specific binding was essentially linear with up to $1 \mathrm{~g}$ wet liver/ml (final concentration of incubate) when it reached a plateau, demonstrating that up to $40 \%$ of the ${ }^{125} \mathrm{I}_{\mathrm{sGH}} \mathrm{S}_{2}$ may be bound to the receptors.

When a constant amount of liver preparation was incubated with an increasing concentration of ${ }^{125} \mathrm{I}-\mathrm{sGH}_{2}$, nonspecific binding behaved linearly and was not saturable, while specific binding was saturable (Fig. 7). The Scatchard derived curve revealed a single class of binding sites with a binding capacity of $187 \pm 167 \mathrm{pmol}(n=4$; $1.6 \mathrm{pmol} / \mathrm{g}$ tissue) and a high binding affinity $\left(K_{a}=2.4 \pm 0.810^{9} M^{-1}, N=4\right)$.

When incubation was carried out with a fixed concentration of labeled hormone, specific binding could be competitively inhibited by increasing the concentration of unlabeled $\mathrm{sGH}_{2}$ (Fig. 8). The concentration of cold $\mathrm{sGH}_{2}$ required to obtain $50 \%$ displacement of ${ }^{125} \mathrm{I}_{-} \mathrm{sGH}_{2}$ was about $40 \mathrm{ng} / \mathrm{ml}$.

Gonadotropins, thyrotropins, and prolactin from mammals or chinook salmon had no significant effect on binding (Fig. 8). Natural or recombinant mammalian GH inhibited ${ }^{125} \mathrm{I}_{-} \mathrm{sGH}_{2}$ binding, but $50 \%$ inhibition required a hormone concentration about 30 -fold higher than that required when using $\mathrm{sGH}_{2}$. Chinook salmon $\mathrm{GH}_{1}$ and sea bream $\mathrm{GH}$ appeared to be 2-fold less effective than cold $\mathrm{sGH}_{2}$.

\section{${ }^{125}$ I-sGH Binding to Different Tissue Preparations}

The liver preparation bound ${ }^{125} \mathrm{I}-\mathrm{sGH}_{2}$ to a much greater extent than the other tissue preparations, especially if we took into account the tissue concentrations of each tissue (Fig. 9). However, preparations from ovary, testis, fat, skin, cartilage, gill, blood pellet, brain, spleen, kidney, and muscle revealed significant specific binding. Only intestine and stomach preparations were ineffective, but showed high nonspecific binding.

\section{DISCUSSION}

In the present study, we used a chinook 


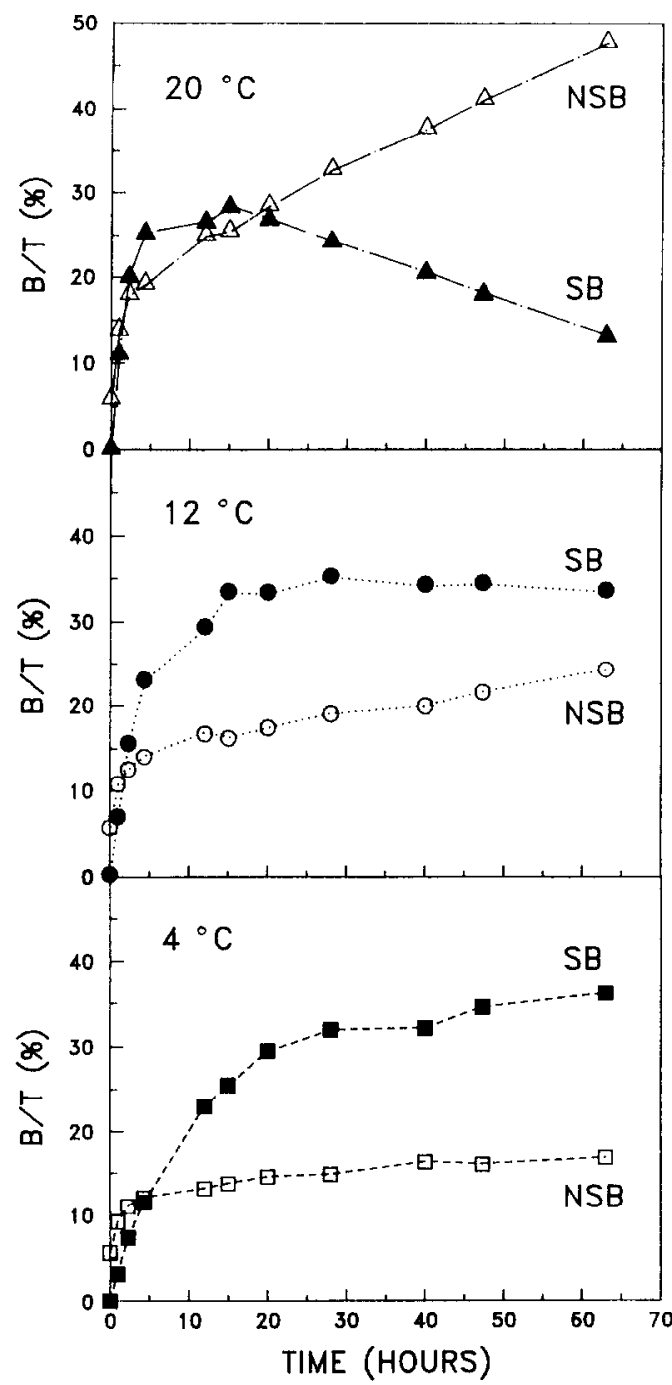

Fig. 4. Effect of time and temperature on specific (SB) and nonspecific (NSB) binding of ${ }^{125} \mathrm{I}-\mathrm{sGH}_{2}$ to liver preparation ( $100 \mu \mathrm{l}$ of $2 \mathrm{~g} / \mathrm{ml}$ wet tissue).

salmon $\mathrm{GH}$ to characterize $\mathrm{GH}$ receptors in rainbow trout liver. There is only one amino acid difference between the GHs of these two species (Hew et al., 1989; Agellon and Chen, 1986), whereas the two forms of rainbow trout GHs differ with respect to 11 amino acids (Rentier-Delrue $e t$ al., 1989). Taking these conditions into account, we consider that our study was done in a homologous system. Labeled $\mathrm{sGH}_{2}$ shows a high and homogeneous ability to bind.

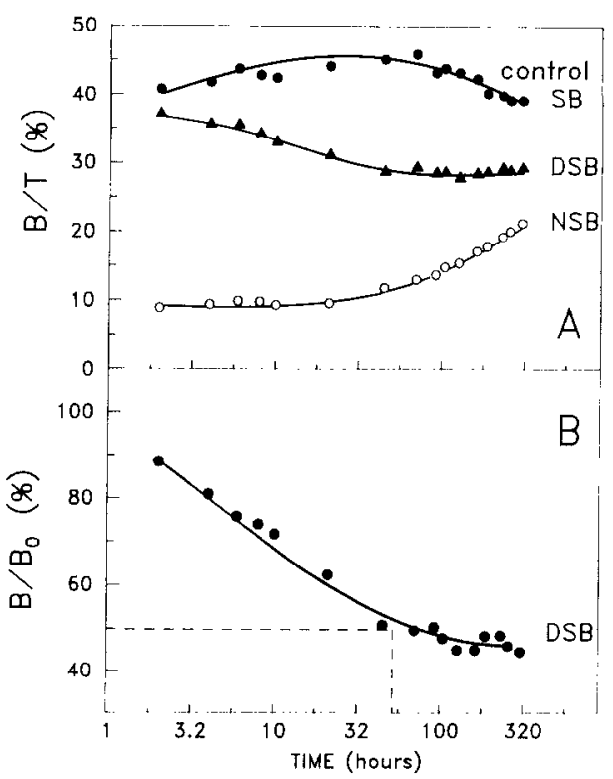

FIG. 5. Dissociation kinetics of ${ }^{125} \mathrm{I}-\mathrm{sGH}_{2}$ from hepatic preparation at $12^{\circ}$. After $20 \mathrm{hr}$ of liver preparation $(100 \mu \mathrm{l}$ of $1 \mathrm{~g} / \mathrm{ml}$ wet tissue) preincubation with ${ }^{125} \mathrm{I}-\mathrm{sGH}_{2}(20,000 \mathrm{cpm} / 100 \mu \mathrm{l})$ and $50 \mu \mathrm{l}$ of buffer with (NSB) or without (SB) cold sGH $(10 \mu \mathrm{g})$, cold sGH (10 $\mu \mathrm{g} / 50 \mu \mathrm{l})(\mathrm{DSB}=$ dissociated specific binding) or buffer $(50 \mu \mathrm{l})$ (control SB and NSB) was added. Results were expressed as percentages of ${ }^{125} \mathrm{I}-\mathrm{sGH}_{2}$ added (A) or as percentages of control specific binding (B).

Before characterizing the receptors, we looked for the optimal incubation conditions. A crude liver preparation was used because the liver membrane preparation obtained by serial centrifugation in sucrose solution (Tsushima and Friesen, 1973) lost $30 \%$ of its binding capacity, nonspecific binding staying unchanged. Optimal incubation pHs obtained in this study corresponded to those found by Tarpey and Nicoll (1985) in mudsucker and sturgeon using bovine $\mathrm{GH}$ and that found by Breton et al. (1986) in rainbow trout using chinook $\mathrm{GtH}$. An important sensitivity of the specific binding to salt concentration (Tris or $\left.\mathrm{MgCl}_{2}\right)$ during incubation was observed. The incubation conditions ( $5 \mathrm{mM} \mathrm{MgCl}_{2}, 20$ $\mathrm{m} M$ Tris) we retained are different from the physiological situations, in which salt concentration is more than 10 -fold higher. Un- 


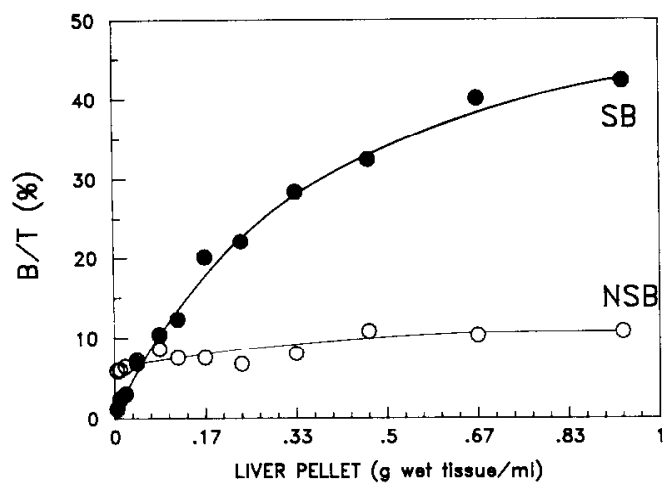

FIG. 6. Effect of the amount of liver preparation on specific (SB) and nonspecific (NSB) binding of ${ }^{125} \mathrm{I}$ $\mathrm{sGH}_{2}$. The incubation conditions are described under Materials and Methods.

der these conditions, the apparent $K_{a}$ and the number of sites found in our study, as well as in other work done on GH receptors, might not reflect the in vivo situation.

The binding of ${ }^{125} \mathrm{I}$-sGH to liver membranes was time and temperature dependent. The decline in specific binding observed after $15 \mathrm{hr}$ at $20^{\circ}$ could be due to a degradation of labeled hormone, as the increase in nonspecific binding suggests. A similar phenomenon was previously reported with high, nonphysiological temperatures in trout (Ikuta et al., 1989), eel (Hirano and Kishida, 1989), and mudsucker (Tarpey and Nicoll, 1985). At $4^{\circ}$, specific binding equilibrium was reached after 28 $\mathrm{hr}$, which is in agreement with Ikuta et al. (1989), but which differs with results obtained in eel (12 hr) (Hirano and Kishida, 1989) and rabbit ( $80 \mathrm{hr}$ ) (Gerasimo et al., 1979). While $50 \%$ of the binding could be displaced after $48 \mathrm{hr}$ in the presence of a large excess of sGH, more than $45 \%$ of the specific binding could not be dissociated even after 13 days. Similar phenomena have been noted for $\mathrm{GH} /$ receptor binding in rabbit (Gerasimo et al., 1979). Such nonreversible binding of the hormone to its receptor might correspond to a first step of the internalization process as was found in human chorionic gonadotrophin-receptor interaction (Catt et al., 1980).

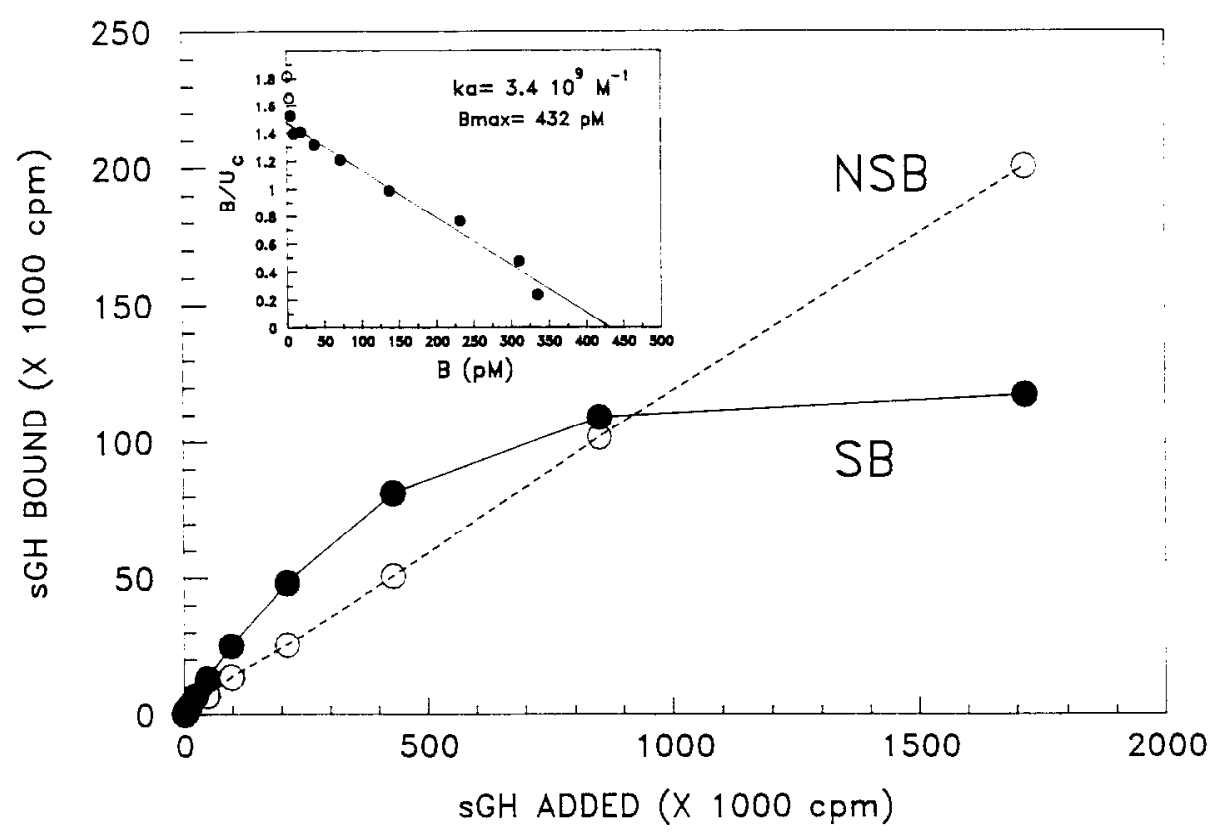

FIG. 7. Effect of increasing concentrations of ${ }^{125} \mathrm{I}-\mathrm{sGH} \mathrm{GH}_{2}$ on specific (SB) and nonspecific (NSB) binding to liver preparation ( $100 \mu \mathrm{l}$ of $1 \mathrm{~g} / \mathrm{ml}$ wet tissue). The inset shows the derived Scatchard plot. The incubation was carried out at $12^{\circ}(20 \mathrm{hr})$. 


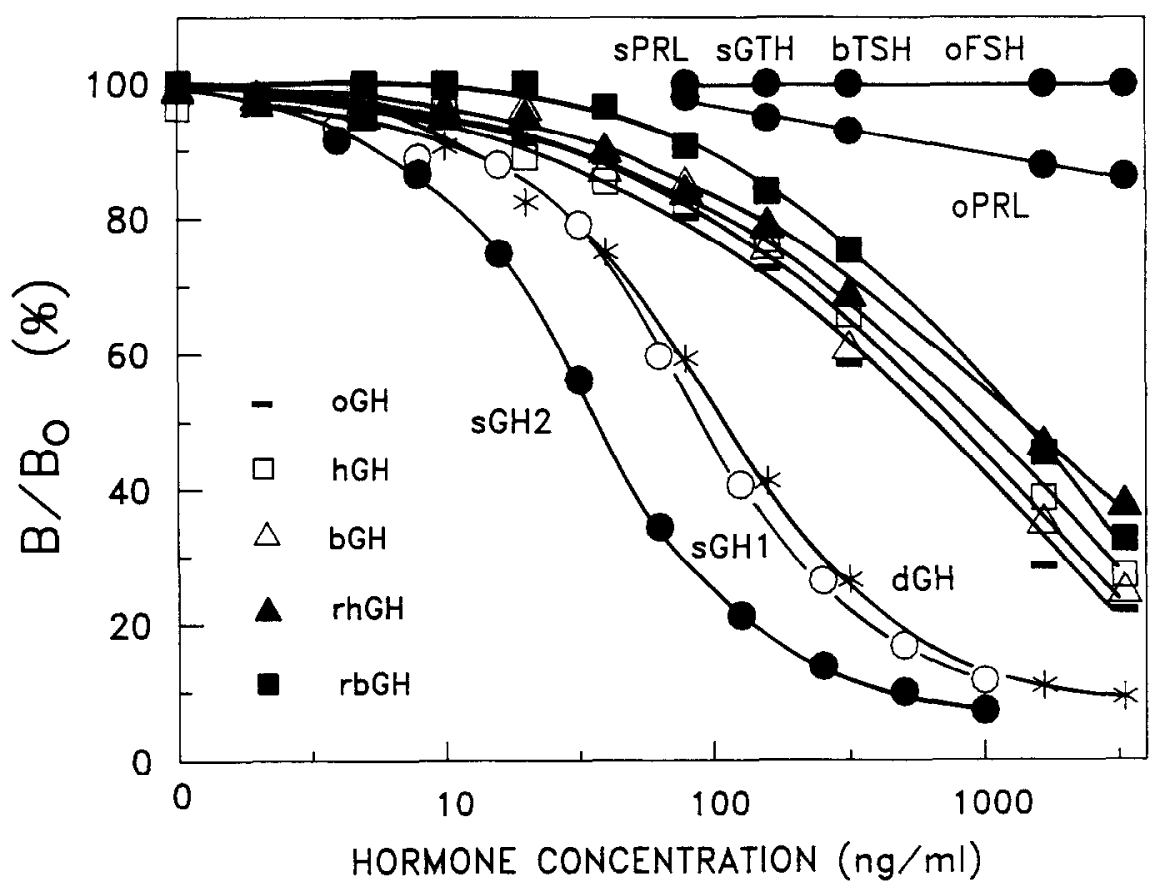

FIG. 8. Competitive inhibition curves for specific binding of ${ }^{125} \mathrm{I}-\mathrm{sGH}_{2}(20,000 \mathrm{cpm} / 100 \mu \mathrm{l})$ to liver preparation $(100 \mu \mathrm{l}$ of $0.5 \mathrm{~g} / \mathrm{ml}$ wet tissue) by increasing various hormone preparations expressed in $\mathrm{ng} / \mathrm{ml}$ (final concentration). Binding is expressed as a percentage of ${ }^{125} \mathrm{I}-\mathrm{sGH}_{2}$ specific binding in the absence of competition.

The Scatchard plot derived from the saturation curve gave only one class of binding site, showing an affinity constant $\left(K_{a}=2.4\right.$ $\pm 0.810^{9} M^{-1}, N=4$ ) similar to that found in trout by Ikuta et al. (1989) and of the same order of magnitude as those found in mammalian liver using homologous hormones as in rabbit (Hughes, 1979), cattle (Hung et al., 1985), sheep (Glukman et al., 1983), mice (Haro and Talamantes, 1985), and human (Carr and Friesen, 1976). The trout affinity constant appears to be one order of magnitude lower than that of tilapia (Fryer, 1979b) and two orders of magnitude lower than that of sturgeon (Tarpey and Nicoll, 1985) using bovine GH. We also found that mammalian $\mathrm{GH}$ could bind to the trout liver preparation but with a much lower affinity as shown by the high concentrations necessary to inhibit ${ }^{125}{ }^{-}-\mathrm{sGH}_{2}$ binding. This result corroborates the lower biological activity of mammalian $\mathrm{GH}$ on salmonid growth (see Donaldson et al., 1979) as compared to the growth-promoting effect of the homologous hormone (Kawauchi et al., 1986). Conversely, salmon GH or salmonid pituitary extracts are able to bind mammalian receptors (Nicoll et al., 1987; Le Bail et al., 1989; Niu et al., 1990) but also with a lower affinity than mammalian hormones. Sea bream GH was highly efficient in inhibiting the ${ }^{125} \mathrm{I}-\mathrm{sGH}_{2}$ binding, which suggests a similar structure between these two hormones. $\mathrm{sGH}_{1}$ seemed to be less potent than $\mathrm{sGH}_{2}$ in displacing labeled $\mathrm{sGH}_{2}$. However, it is difficult to draw conclusions without knowing the "biochemical quality" of the $\mathrm{sGH}_{1}$ used, which can vary from one purification to another.

The number of binding sites found (1.6 $\mathrm{pmol} / \mathrm{g}$ tissue) was equivalent to the value reported by Ikuta et al. (1989) $(2.46 \mathrm{pmol} / \mathrm{g}$ tissue) but appeared to be very variable. According to our observation (unpublished 


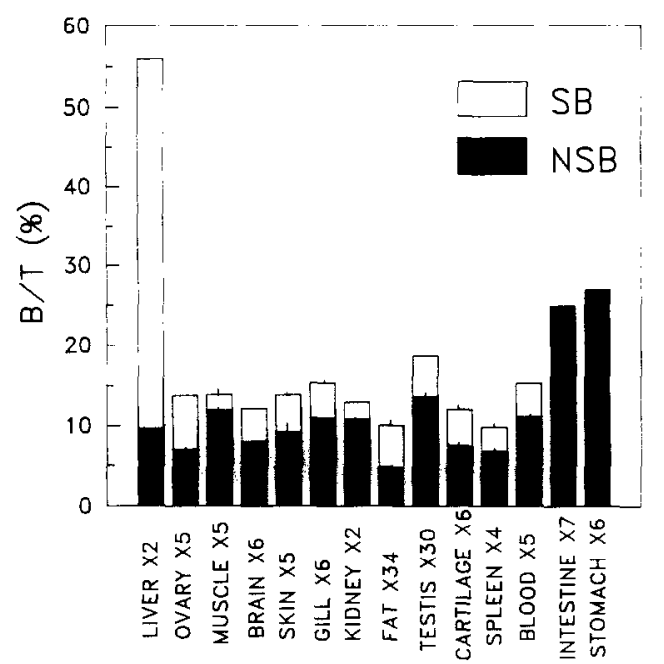

FIG. 9. Specific and nonspecific binding of ${ }^{125} \mathrm{I}$ $\mathrm{sGH}_{2}$ to different trout tissues. Tissue preparations $(100 \mu \mathrm{l})$ at a given dilution $(\times 2=2 \mathrm{~g} / \mathrm{ml}$ of wet tissue) were incubated as described under Materials and Methods. The specific (SB) and the nonspecific (NSB) binding are expressed as percentages of the total added ${ }^{125} \mathrm{I}-\mathrm{sGH}_{2}$. Histograms are the means of duplicate determinations and the vertical bars represent the distance between the mean and the superior value. Absence of bar signifies that the duplicates coincide.

data), this variability can be explained in part by the different sexual stages and degrees of nutrition of the animal used in this study. Fryer and Bern (1979) and more recently Gray et al. (1989) demonstrated that specific binding of $\mathrm{GH}$ is lower in stunted than in normal coho salmon. In mammals, variations of $\mathrm{GH}$ binding were also observed during pregnancy (Posner, 1976; Gerasimo et al., 1979) and starvation (see Postel-Vinay et al., 1987). All the properties observed with the trout liver preparation, a finite number of binding sites, high affinity, and hormone specificity, are characteristic of hormonal receptors.

Binding sites were looked for in other tissues. Only intestine and stomach did not show binding sites. 'This could result from ${ }^{125} \mathrm{I}$-sGH degradation by digestive enzymes as suggested by the high nonspecific binding observed. All other tissues tested demonstrated saturable binding but at a level considerably lower than that of the liver preparation. The presence of saturable $\mathrm{GH}$ binding in kidney and gill was also noted by Ikuta et al. (1989) in rainbow trout and masu salmon (O. masou) and by Fryer (1979b) in tilapia. The presence of GH receptors in these osmoregulatory organs together with the facilitating effect of GH pretreatment for salmonid adaptation to seawater (Komourdijan et al., 1976; Clarke et al., 1977; Bolton et al., 1987; Boeuf et al., 1990) would support the hypothesis of a role for $\mathrm{GH}$ in osmoregulation. In mammals, direct effects of $\mathrm{GH}$ or the presence of $\mathrm{GH}$ receptors was found in tissues implicated in growth function, such as fat (Fagin et al., 1980; Gavin et al., 1982; Digirolamo et al., 1986), skin (Murphy et al., 1983), cartilage (Eden et al., 1983), and muscle (Daughaday, 1977). Saturable GH binding was also found in muscle of rainbow trout, masu salmon, and char (Salvelinus pluvius) (Ikuta et al., 1989). The presence of a putative GH receptor in brain suggests a possible GH autofeedback control via the hypothalamus. In blood cells, the saturable binding cannot be attributed to possible serum contamination since our previous work has shown that in trout, blood plasma proteins do not specifically bind salmonid $\mathrm{GH}$ (Niu et al., 1990), but it can be explained by the presence of lymphocytes in which $\mathrm{GH}$ receptor was characterized in human (Lesniak et al., 1974).

In rat gonads, a GH receptor has not yet been demonstrated, but in vitro studies have shown that GH was able to increase the IGF $_{1}$ secretion by ovary (Hsu and Hammond, 1980) and testes (Tres et al., 1983). In fish, a strong relationship exists between growth and reproduction (Le Bail, 1988), and injection of sGH can increase the steroid production (Singh et al., 1988; Van der Kraak et al., 1989). In vitro, $\mathrm{GH}$ alone or in synergy with GtH increases the steroid production by gonads (Singh et al., 1988; Van der Kraak et al., 1989; Le Gac et al., unpublished data). So, the GH saturable bind- 
ing we found in trout testis and ovary arc in agreement with these physiological data.

However, saturable binding alone cannot be equated with the presence of receptor and further investigation is necessary to establish the presence of $\mathrm{GH}$ receptor in tissues other than liver.

\section{ACKNOWLEDGMENTS}

We are indebted to the National Institute of Arthritis, Diabetes, Digestive and Kidney Diseases; to Sanofi; and to Monsanto for the purified and recombinant mammalian hormones. We are especially grateful to Dr. Breton and Dr. Prunet for their gifts of chinook salmon GtH and Prl. We acknowledge Miss V. Ploteau, Ms. Le Guevel, and Ms. Hall for their assistance in the preparation of the manuscript. This work is the result of investigations supported in part by a grant of GCS, "Base Biologique de l'Aquaculture", in part by an AIP (INRA) grant, "Mecanismes Cellulaires et Endocriniens de la Croissance" and in part by the "Région Bretagne."

\section{REFERENCES}

Agellon, L. B., and Chen, T. T. (1986). Rainbow trout growth hormone: Molecular cloning of CDNA and expression in Escherichia coli. DNA 5, 463-477.

Boeuf, G., Prunet, P., and Le Bail, P. Y. (1990). Un traitement à l'hormone de croissance peut-il stimuler la smoltification du saumon Atlantique? C.R. Acad. Sci. Ser. 3 310, 75-80.

Bolton, J. P., Collie, N. L., Kawauchi, H., and Hirano, T. (1987). Osmoregulatory actions of growth hormone in rainbow trout (Salmo gairdneri). J. Endocrinol. 112, 63-68.

Breton, B., Le Gac, F., and Sambroni, E. (1986). Gonadotropin hormone $(\mathrm{GtH})$ receptors in the ovary of the brown trout Salmo trutta L. in vitro studies. Gen. Comp. Endocrinol. 64, 163-171.

Breton, B., Prunet, P., and Reinaud, P. (1978). Sexual differences in salmon gonadotropin. Ann. Biol. Anim. Biochim. Biophys. 18, 759-765.

Breton, B., and Sambroni, E. (1989). Evolution du nombre des récepteurs gonadotropes ovariens au cours du cycle reproducteur annuel chez la truite fario Salmo trutta L. C.R. Acad. Sci. Ser 3308 , 495-500.

Carr, D., and Friesen, H. G. (1976). Growth hormone and insulin binding to human liver. J. Clin. Endocrinol. Metab. 42, 484-493.

Catt, K. J., Harwood, J. P., Clayton, R. N., Davies, T. F., Chan, V., Katikineni, M., Nozu, K., and Dufeau, M. L. (1980). Regulation of peptide hor- mone receptors and gonadal steroidogenesis. $R e$ cent Prog. Horm. Res. 36, 557-621.

Clarke, W. C., Farmer, S. W., and Hartwell, K. M. (1977). Effect of teleost pituitary growth hormone on growth of Tilapia mossambica and on growth and sea water adaptation of sockeye salmon $(\mathrm{On}$ corhynchus nerka). Gen. Comp. Endocrinol. 33, 174-178.

Dauder, S. D., Young, G., Hass, L., and Bern, H. A. (1990a). Prolactin reccptors in liver kidney and gill of the tilapia (Oreochromis mossambicus): Characterization and effect of salinity on specific binding of iodinated ovine prolactin. Gen. Comp. En docrinol. 77, 368-377.

Dauder, S. D., Young, G., and Bern, H. A. (1990b). Effect of hypophysectomy replacement therapy with ovine prolactin and cortisol and triiodothyronine treatment on prolactin receptors of the $\mathrm{Ti}$ lapia (Oreochromis mossambicus). Gen. Comp. Endocrinol. 77, 378-385.

Daughaday, W. H. (1977). GH receptor and radioreceptor assay. In "Endocrine Control of Growth" (W. H. M. D. Daughaday, Ed), pp. 2-8. Elsevier, Amsterdam.

Digirolamo, M., Eden, S., Enberg, G., Isaaksson, O., Lonnroth, P., Hall, K., and Smith, U. (1986). Specific binding of human growth hormone but not insulin-like growth factors by human adipocytes. FEBS 205, 15-19.

Donaldson, E. M., Fagerlund, U. H. M., Higgs, D. A., and McBride, J. K. (1979). Hormonal enhancement of growth. In "Fish Physiology" (W. S. Hoar, D. J. Randall, and J. R. Brett, Eds.), Vol. 8, pp. 456-478. Academic Press, New York/London.

Eden, S., Isaaksson, O. G. P., Madsen, K., and Friberg, U. (1983). Specific binding of growth hormone to isolated chondrocytes from rabbit ear and epiphyseal plate. Endocrinology 112, 11271129.

Edery, M., Young, G., Bern, H. A., and Steiny, S. (1984). Prolactin receptors in tilapia (Sarotherodon mossambicus) tissues: Binding studies using ${ }^{125}$ I-labeled ovine prolactin. Gen. Comp. Endocrinol. 56, 19-23.

Fagin, K. D., Lackey, S. L., Reaggan, C. R., and Digirolamo, M. (1980). Specific binding of growth hormone by rat adipocytes. Endocrinology 107, 608-615.

Fryer, J. N. (1979a). Prolactin-binding sites in tilapia (Sarotherodon mossambicus) kidney. Gen. Comp. Endocrinol. 39, 347-403.

Fryer, J. N. (1979b). A radioreceptor assay for purified teleost growth hormone. Gen. Comp. Endocrinol. 39, 123-130.

Fryer, J. N., and Bern, H. A. (1979). Growth hormone binding to tissues of normal and stunted ju- 
venile coho salmon Oncorhynchus kisutch. J. Fish Biol. 15, 527-533.

Gavin, J. R., III, Saltman, R. J., and Tollefsen, S. E. (1982). Growth hormone receptor in isolated rat adipocytes. Endocrinology 110, 637-643.

Gerasimo, P., Djiane, J., and Kelly, P. A. (1979). Titration of total binding sites for growth hormone in rabbit liver. Mol. Cell. Endocrinol. 13, 11-23.

Gluckman, P.D., Butler, J. H., and Elliot, T. B. (1983). The ontogeny somatotropic binding sites in ovine hepatic membranes. Endocrinology 112, 1607-1612.

Gray, E. S., Young, G., and Bern, H. A. (1989). Radioreceptor assay for salmon $\mathrm{GH}(\mathrm{sGH})$ and analysis of hepatic binding sites in normal and stunted salmon. Amer. Zool., in press.

Greenwood, F. C., Hunter, W. M., and Glover, J. S. (1963). The preparation of ${ }^{131} \mathrm{I}$ labelled human $\mathrm{GH}$ of high specific radioactivity. Biochem. J. 89, 114-123.

Haro, L. S., and Talamantes, F. J. (1985). Internalization of mouse prolactin with mouse hepatic receptors. Mol. Cell. Endocrinol. 41, 93-104.

Hew, C. L., Trinh, K. Y., Du, S. J., and Song, S. (1989). Molecular cloning and expression of salmon pituitary hormones. Fish Physiol. Biochem. 7, 375-380.

Hirano. T., and Kishida, M. (1989). Growth hormone receptors in the eel liver. In "Proceedings, XIth International Symposium on Comparative Endocrinology," p. 160. Malaga, May 1989. [Abstract]

Hsu, C. J., and Hammond, J. M. (1980). Growth hormone stimulates insulin-like growth factor- 1 and progesterone secretion by porcine granulosa cells in culture. In "19th Annual Meeting of the Society for the Study of Reproduction." New York, July 1980 [Abstract]

Hughes, J. P. (1979). Identification and characterization of high and low affinity binding sites for growth hormone in rabbit liver. Endocrinology $105,414-420$.

Hung, C. H., Kover, K., and Moore, W. V. (1985). Characterization of somatotropic growth hormone binding to homologous liver plasma membranes. Mol. Cell. Endocrinol. 39, 189-196.

Ikuta, K., Hirano, T., and Aida, K. (1989). Radioreceptor assay for salmon growth hormone. In "Proceedings, XIth International Symposium on Comparative Endocrinology," p. 168. Malaga, May 1989. [Abstract]

Kanamori, A., Kagawa, H., and Nagahama, Y. (1987). Gonadotropin receptors in the postovulatory ovary of Amago Salmon (Oncorhynchus rhodurus). Gen. Comp. Endocrinol. 66, 210-217.

Kanamori, A., and Nagahama, Y. (1988). Developmental changes in the properties of gonadotropin receptors in the ovarian follicles of Amago Salmon (Oncorhynchus rhodurus) during oogenesis. Gen. Comp. Endocrinol. 72, 25-38.

Kawauchi, H., Moriyama, S., Yasuda, A., Yamaguchi, K., Shirahata, K., Kubotta, J., and Hirano, T. (1986). Isolation and characterization of chum salmon growth hormonc. Arch. Biochem. Physiol. 244, 542-552.

Komourdijan, M. P., Saunders, R. L., and Fenwick, J. C. (1976). The effect of porcine somatotropin on growth and survival of Atlantic salmon (Salmo salar). Canad. J. Zool. 54, 534-535.

Le Bail, P. Y. (1988). Growth-reproduction interaction in salmonids: Proceedings of the French Israeli symposium, Tel Aviv, November 10-12, 1986, INRA Paris. In "Reproduction in Fish: Basic and Applied Aspects in Endocrinology and Genetics," pp. 91-108.

Le Bail, P. Y., Boulard, G., Barenton, B., and Zygmunt, M. (1989). Purification of chinook salmon (Oncorhynchus tshawytscha) GH for receptor study. Fish Physiol. Biochem. 7, 243-251.

Le Gac, F., Breton, B., and Bougoussa, M. (1988). Gonadotropic hormone $(\mathrm{GtH})$ receptors in the testis of the trout Salmo gairdneri: In vitro studies. Fish Physiol. Biochem. 5, 209-217.

Lesniak, K. A., Gorden, P., Roth, J., and Garvin, J. R., III. (1974). Binding of human growth hormone to specific receptors in human cultured lymphocytes. J. Biol. Chem. 249, 1661-1667.

Martal, J. (1972). Détermination radioimmunologique des hormones de croissance ovine et bovine: étude des conditions d'iodation et obtention d'une hormone somatotrope radioiodée sans prolactine contaminante. C.R. Acad. Sci. 274, 2893-2896.

Murphy, L. J., Vrhovsek, E., and Lazarus, L. (1983). Identification and characterization of specific growth hormone receptors in cultured fibroblasts. J. Clin. Endocrinol. Metab. 57, 1117-1123.

Nicoll, C. S., Steiny, S. S., King, D., Nishioka, R. S., Mayer, G. L., Eberhardt, N. L., Baxter, J. D., Yamanaka, M. K., Miller, J. A., Seilhamer, J. J., Schilling, J. W., and Johnson, L. K. (1987). The primary structure of coho salmon growth hormone and its cDNA. Gen. Comp. Endocrinol. 68, 387-399.

Niu, P. D., Le Gac, F., and Le Bail, P. Y. (1990). Presence of human growth hormone binding protein in rainbow trout (Oncorhynchus mykiss). Submitted for publication.

Posner, B. I. (1976). Characterization and modulation of growth hormone and prolactin binding in mouse liver. Endocrinology 98, 645-654.

Postel-Vinay, M. C., Kayser, C., and Bullier-Picard Clot, J. P. (1987). Regulation des récepteurs et mécanismes d'action de l'hormone de croissance. Reprod. Nutr. Dev. 27(2B), 513-520. 
Prunet, P., and Houdebine, L. M. (1984). Purification and biological characterization of Chinook salmon prolactin. Gen. Comp. Endocrinol. 53, 49-57.

Rentier-Delrue, F., Swennen, D., Mercier, L., Lion, M., Benrubbi, O., and Martial, J. A. (1989). Molecular cloning and characterization of two forms of trout growth hormone cDNAs. Expression and secretion of tGH-II by Escherichia coli. DNA 8, 109-117.

Salmon, C., Kagawa, H., Adachi, S. Nagahama, Y., and Fontaine, Y. A. (1984). Mise en évidence de sites de liaison spécifiques de la gonadotropine de saumon chum (Oncorhynchus keta) dans les préparations membranaires de granulosa d'ovaire de saumon amago (Oncorhynchus rhodurus). C.R. Acad. Sci. Paris Ser 3 298, 337-340.

Singh, H., Griffith, R. W., Takahashi, A., Kawauchi, H., Thomas, P., and Stegeman, J. J. (1988). Regulation of gonadal steroidogenesis in Fundulus heteroclitus by recombinant salmon growth hormone and purified salmon prolactin. Gen. Comp. Endocrinol. 72, 144-153.
Scatchard, G. (1949). The attraction of proteins for small molecules and ions. Ann. N.Y. Acad. Sci. $51,660-673$.

Tarpey, J. F., and Nicoll, C. S. (1985). Characterization of hepatic growth hormone binding sites in two fish species Gillichthys mirabilis (teleostei) and Acipenser transmontanus (chondrostei). Gen. Comp. Endocrinol. 60, 39-50.

Tres, L. L., Smith, E., Van Wyk, J. J., and Kierszenbaum, A. L. (1983). Somatomedin-C in rat Sertoli-spermatogenic cell coculture. J. Cell. Biol. 97(18a). [Abstract]

Tsushima, T., and Friesen, H. G. (1973). Radioreceptor assay for growth hormone. J. Clin. Endocrinol. 37, 334-337.

Van der Kraak, G., Rosenbloom, P., Peter, R. E., and Danzmann, R. G. (1989). The positive effects of growth hormone on steroidogenesis in fish. In "Proceedings, Satell. Symp. Appl. Comp. Endocrinol. Fish Cult.," Almunecar, May 1989, p. 76. [Abstract] 